\title{
林 先生の足跡を訪ねて
}

\author{
— 1950 年代の頃——
}

\author{
高 倉 節 子
}

林先生の追悼号を出版されるとのことで, 先生の初 期の頃（1947 年から'64 年まで，筆者が先生の仕事の お手伝いをしていた頃）の大きな業績, 根本的な考元 方などの一部を辿り，記述していった.「これだけの理 解しかできていなかったのか」と先生の扔叱りの声が 聞こえてくるようである.先生のご冥福を祈りつつ, 拙 いものを書かせて頂いた。

林先生の統計への出発点は, やはり, Von Mises の 確率論との出会いであったと思う。先生が，確か，眼 から鱗が落ちたような，大きな感激で，Mises を読ん だ，といわれたことが，大変印象的に記憶に残ってい る.

Mises の考元の Kollektiv の上に確率が定義される ということが,まさに行為的立場に立った数学であり, それが林先生が求めていらしたものであったのだと思 える. 先生は, よく「行為的立場」一或いは「操作的 立場」一という言葉を使われておられたと思う。先生 の科学は, すべて,「行為」の上に編まれていくもので あったのだと思える. 理論の精緻な建立で成り立って いる数学の世界の中で, 繰り返しの試行行為, 一偶然 性一を数学的に美しく表現した Mises の Kollektiv に涙を流さんばかりに感動された先生の気持ちが解る ように思える. 先生ご自身の著作の中にも，「無規則性 を其本質として偶然の一表現を試みようとする美しい 象徵的なこれくていふの思想は Richard Von Mises に依って 1919 年の Math Zert に初めて発表せられた ものである. $\lrcorner^{11}$ と書かれている.

先生の考えにはしばしば飛躍がある，ということが 言われているが, Mises の Kolleckiv の定義にある「す べての選出行為」に関して, 多くの議論が沸騰した事 も, 先生の中では, 余りとるに足らない事であったよ うに，言っておられたと記憶する。「Stellenauswahl は 具体的問題解決の為に依ってでなく行為其のものの性 質（性格, 本質）上必然的に其の可附番個なることは
身体的行為をともなって直観せられるのである.した がってすべての Stellenauswahl とは当然直観せられ たものとしての可附番個の種々なる選出行為を意味す るものであると言へよう.」」2) と書いておられ，更に， 「此の本質を見失い形式的に「すべての」を解釈するこ とは Stellenauswahl と言う行為の固定的表現に固執 して其の概念的なもののみの間に推理を尽したもので あって偶然其のものに基底を置くが故に行為としての Stellenauswahl をもち来った Kollektiv 理論の真意 を解せぬものと思はれる.」3) と書かれている。この 「これくていふ序説 (I)」には, その後の林先生の理論 の展開の基盤となる「直観的」,「実践的」,「行為的立 場」への傾倒が Kollektiv 理論の展開と共に, 熱っほくく 示されていると見られよう.

先生は, 自然科学の分野にも興味を持っておられ, 後 に, 医学の分野や野ウサギの行動範囲を押さえた上で の残存数の予測等に, 大きな力を注がれたが, 最初の ころは, むしろ, 社会現象の統計的解析や予測に多大 の関心を持っておられたと思う。

そして，第一の大きな仕事が「仮釈放の予測」であっ たと思える。

刑法学者であり, 当時法務府中央刑務官練習所の調 查普及課長であった西村克彦氏が，仮釈放の予測の問 題について, 統計的アプローチに関して林先生の所に 相談に来られたのは，'47 年の秋頃であったであろう か. それは, 先生のその後の研究の方向づけとなるも のであったと云えよう.

当時, その種の先行研究は, 日本においては皆無に 等しかったが，アメリカにおける研究には参考になる ものがあった。しかし，それも統計学的には十分なも のではなく, 理論的基礎付けも確たるものではなかっ た. そこで先生は, 先行研究を参考にしながらも, 統 計学的な基準に基づいた新たな方法の展開を考えられ 
たのであるそそこでは，仮釈放失敗者，成功者の判別 予測の精度を高めるための要因を探索し，判別の基準 を設定し，これによる判別的中率を最大にするように 要因に数值を与える方法を開拓された。これには，西 村氏がかつて勤務しておられた横浜刑務所の受刑者を 対象に, ナマのデー夕を収集し, 再犯のおそれのある, 無しに関して, 受刑者の特性を調べ, これを分析し, 方 法の定式化を考案されたのであった。

この「仮釈放予測」の研究において, 当に林先生の 統計的研究の礎が築かれたといってよいであろう. 即 ち，ある社会的現象を解析するに当たって，目的を明 確にした上で，その目的に適った克明なデー夕を収集 するということ，デー夕について種々分析を進めてゆ く中から最適な方法を見いだしていくということ，そ して，社会現象に対して科学的にアプローチするなら ば，そこには，「予測」ということが要であること一(後 に先生は,「科学の目的は予測にあるといってよい」) と書いておられる。）—，そして，定性的な要因に対 して数量を与える, という, 先生の基本的な原則がしっ かりと根を下ろしたといえよう。

1946 年当時, 統計数理研究所は理論的研究を行う理 論研究部（第 1 部）と応用研究部（第 2 研究部）に分 かれていたが, ’ 46 年 4 月に大改革がなされ，既成の部 は, それぞれ基礎理論研究部, 自然科学研究部に移行 され，新たに第 3 研究部として社会科学部が新設され た.この大改革後, ' 47 年夏頃に林先生は, 水野坦先生 と共に第 3 研究部に移って来られた。この第 3 研究部 では,特に社会現象の統計的解析が重要な仕事であり, 当時, 第 3 研究部は, 大蔵省理財局の一室を借りてい たことから，大蔵省関係の仕事（例えば，所得実態調 查, 国富の調查等)も大きな仕事であった。しかし，何 といっても，その当時，第 3 部を挙げて殆ど総力で当 たった仕事は「読み書き能力の調査」であった。

それは当時, 識者の中にも漢字が難解であるという 認識から，日本語をローマ字化した方がよいという意 見の人もあり，特に実際的な政策の最高権威であった G.H.Q.（連合国軍総司令部）の強い意向もあって, 日 本人の読み書きの能力を調査することになった。「この 仕事は日本の国語をどうあらためたらよいかと言うこ とを考究する為の一つの基本資料をうるために設けら れた「読み書き能力調査委員会」の中でなされたもの である」と林先生が書かれている5

「読み書き能力」とは,「社会の一員の正常な生活に
最小限度に必要な型及び度合の文字言語を使用する能 力」と定義づけられており ${ }^{6)}$, 新聞, 雑誌, 公文書, 一 般国民の職業に関する行為, 私信等に用いられる文字, 言語の読み書きの能力と考えられた.調查委員会は, 言 語, 国語, 教育, 心理, 社会, 統計, 新聞・雑誌の各 部門からの専門家によって構成され，統計部門の専門 委員として林先生が加わられた. 調查の対象は, 通常 の社会生活を営めると考えられる 15 歳から 64 歳まで （何れも数元年）の日本人と定められ，全国で約 4,500 万人程度が調査対象集団をなすとみられた．調查の問 題は, 言語, 国語, 心理, 教育の委員によって作成さ れ, 標本調査を中心とする調査の企画は, 林先生が中 心となって行われた。調查は, 被調查者に対し同一条 件の下で解答してもらわなければならず，集合調査で 行わなければならなかった。そこで，どこで何人の被 調査者を集め, 誰が問題についての教示に当たるか等, 細かい計画を立てることも必要であった，当時，約 4,500 万人もの国民を対象集団とした全国規模の標本 調査の実施は初めての事であり, 標本調査ということ に余り経験のなかった林先生を始め統計関係のスタッ フは, 先ず標本調查について学ぶことから始めなけれ ばならなかった。当時, 標本調查に関する参考文献は 殆どなく，アメリカの文献はあったものの手に入れる 方策もなく，C.I.E. (民間情報教育局) の図書館にあっ た文献をポータブルのタイプライターを持参して写し てきて, それを第 3 部の所員の間で备し読みし，知識 を得たという状態であった。 そのような文献による知 識の吸収から, 実際にサンプリング計画を立て実施し, 被調查者の抽出, 調查の実施, 集計・分析, 報告書の 作成までを 1 ケ年の中に成し遂げたということは, 当 時のスタッフが，林先生を中心に文字通り寝食を忘れ てそれに当たったことが容易に推察できよう。

この標本調査は, 後のサンプリングによる全国調査 のモデルとなるものであった。即ち, 全国規模で, 層 別多段無作為抽出法によるサンプルの抽出は現今で は，どこでも行われていることであるが，この調査が 初めての実施であった。

第一次抽出単位としては, 熟慮の後, 全国(但し, 外 海に点在する島嶼を除く）の区，市，郡とし，これを 層化し(郡部は更に町村単位で層化し), 各個人の抽出 される確率を同一にすることとし，人口に比例した確 率で, 区, 市, 郡を抽出し, 郡部の場合は, 更に町村 の抽出を行った。層化に当たっては, 調查の目標であ る読み書き能力に関して，なるべく等質となるように 
行った．即ち，先ず地理的位置により，全国を $6 つ の$ ブロックに分け，各ブロックの中で，市部，郡部に分 け，郡部は更に町村単位で層化し，各層から町又は村 を抽出し，抽出された区，市，町村の中で，割り当て られたサンプル数の被調査者を抽出していった．層化 に当たっては, 都市部に関しては,「先ず，産業率によ りその構成が同じ様なものに区分，更に大工業地区及 び工業地区に分類，次にラジオ聴取率，専門学校以上 の学校数, 交通, 地理的条件, 歴史的状況により層化」 し, 郡部に関しては,「先ず産業構成, 産業の質的構造 によりそれが同じ様になるものを集め層化，次にラヂ 才聴取率, 地理的情況, 人口密度等により層化」し, 郡 部の中の町村に関しては,「生態学的に同一と見なせる ものに層化」によって行われた ${ }^{7)}$.

この層化に用いた項目も，各項目間（例えばラジオ 聴取率と専門学校以上の学校数, 等) の関連を, 量的 な項目に関しては, 相関係数を計算するなどして，そ の項目を層化基準に用いる事の妥当性を検討した上 で，層化の基準となる項目を決めていった（当時，グ ラフはすべて手書き，計算は，そろばんと手廻し計算 機によって行ったのである.)

サンプル数は, 一定の精度が保たれるように計算さ れ, 17,100 という数が得られた ${ }^{8)}$. これに欠席率を考慮 し, 最終的に全国でのサンプル数は 21,008 となった ${ }^{99}$.

なお，サンプリングの実施に当たっては，層別多段 抽出法により調查地点の抽出は元より, 各調査地点ご との被調查者の抽出に当たっても, 調査地点ごとに, ス タートナンバーと, 抽出間隔を定めることも中央（第 3 研究部)で行い, 各調查地点に携わる者の裁量により 行うことを避け, サンプリングの企画実施が誤りなく 行われるように配虑した。

因みに, この調査の計画決定, 実施のスケジュール は次のようにして決まっていった。先ず，読み書き能 力調査の計画は, 1947 年 12 月, C.I.E.の Pelzel 氏が文 部省に打診し, 文部省はそれを教育研修所長に伝えた。 そして, 48 年 1 月に, 同所の国語教育研究室主任は Pelzel 氏から意見を求められ, 所長と相談の結果, そ の計画の樹立を決定し, 1 月 15 日に準備委員会の発足 を見た。そこから専門委員の人選, 調査日程, 予算な どが協議され, 大枠の日程が決まり, 実施が次第に具 体化する中で，次のような調査実施のスケジュール予 定が作られた。即ち, 資料の準備 (文字言語資料, サ ンプリング）が 1948 年 5 月 15 日まで，準備調査と問 題作成も 5 月 15 日まで，実施が 8 月 10 日，分析が 10
月 31 日まで, 吟味調査が 11 月 30 日まで, 報告が 1949 年 2 月 15 日まで，となっていた。

このような層別多段抽出の方法は, その後のサンプ リングによる全国調查 (例えば「国民性の調査」等) に おいても大筋においては, 概ね踏襲されている.コピー 機もなく，計算の道具も原始的なものが用いられてい た時代にも拘わらず，全く正統な層化多段抽出の方法 で, しかも極めて短い期間に, 準備から調查実施, 分 析まで成し遂げられた事は, 偉大な成果であり, 林先 生の大きな業績の一つに数えるべき事であろう.

なお, 林先生はこの結果の分析の過程で定性的な要 因に数量を与えるという，後の数量化 1 類のプロト夕 イプの分析を試みられている。

林先生は, この調査の体験を踏まえて,「サムプリン グ——調査はどう行うか—」の著書を書かれ (1951 年・東京大学出版部発行), 確率論 (Von Mises による) を踏まえたサンプリングの基本理論と技術，サンプリ ング調查の企画の立て方, 読み書き能力調查を主とし たサンプリング調査企画の実例等を丁寧に書いておら れる.このことは, 読み書き能力調査が先生の中にも 確然と植え付けられ, その後の社会調査の開拓への道 に導かれた事を意味するものと考えられよう。

林先生の業績といえば, 誰でもが数量化を考えるで あろう。その芽は仮釈放の予測の研究の中で育てられ (後の数量化 2 類), 次いで, 読み書き能力調査の際の 分析の過程で, 後の数量化 1 類が定式化された. そし て, 1952 年 1 月に社会学, 心理学の専門家と共に行っ た, 某女子大の寮生約 100 名を対象とした「米仏文化 に対する態度調査」の分析の過程で, 先に仮釈放予測 の研究の中で芽を出していた数量化 2 類の方法が定式 化した.

1950 年実施された「国鉄保線区員調査」で，線路の 保守作業に従事している工員間の人間関係と作業能率 の関係を見る研究の中で, 後に数量化 4 類と呼ばれる 方法が開拓された。そして, 1955 年当時武蔵野美術大 におられた佐藤敬之輔氏が持ち込んで来られた缶詰の ラベルデザイン調査で, 好みのデザインとそれを選ぶ 人との関連を分析することから, パタン分類の数量化 (後に数量化 3 類と呼ばれる)が, 定式化された。この ようにして，1950 年代の半ばまでに，4つの数量化の 方法はすべて定式化していたのである ${ }^{10)}$. 後に 1979 年 にフランスの J.P. Benzécri 氏と会い, フランスにおい ても, 数量化 3 類は, Correspondence Analysis と称 
せられて，発想は異なるものの全く同じ解析方法が, 1973 年に発表されていることを知った。しかし，林先 生のこの方法の定式化は, それより約 20 年も早くに発 表されているのである.

林先生は, 仮釈放の予測の研究以来, 「予測」という ことを非常に大切に考元られていた。「予測ということ は非常に大切なものであって広く解釈するならば科学 の目的は予測にあるといってよい」11) と書かれてい る。そして, また,「科学的な予想とは, 予想の信頼度 が確率の意味で保証され，その確率が高いと言うこと であると言ってもよいであろう。これには統計数理の 考え方が必要になってくるのであり，この方法にした がって確率を入れたモデルをつくり, 現象を処理しよ うとすることがなされてくるのである。ここに統計数 理的予想方式と定性的なものの数量化の問題がたちあ らわれてくるのである..$^{12)}$ と予測と統計数理の考元 方との関連を示されている.しかし，「予測の問題 (は) ……単なる確率論的モデルの作成に終わるものでもな い.」13) と理論的に短絡化することを戒めておられる. そして，「確率論的に捉えようとするならば，その フォーミュレーションと現実との対応の妥当性がまず 第一に検討されなければならない.......何者について, 何をいかように予測しようとするかという，その予測 すべき「何者」の決定……，それから次に，……現象 解析に対する目の付け所, これのフォーミュレーショ ン $(\cdots \cdots)$, 解析の基盤となる理論的考察 $(\cdots \cdots \cdot)$, 実 験・調査による諸の資料の獲得, その表現, この分析・ 総合・推論の方法, これの有効・有用性の検討 $(\cdots \cdots \cdot)$ これらの方法論を実際に即して展開する，これに統計 的方法が捧げられることになるのである.」13) と，「予 測」のあるべき姿，なすべき事，統計との関連を綿密 に書いて扔られる，以下，この論文に，先生の「仮釈 放の予測」や「選挙予測」など, 多くの予測の問題に 遭遇し, これを解決し, 納得された論が展開されてい る.

実際, 選挙予測については, 非常に力を入れて来ら れた. 1950 年代の半ばから, 最後の時まで, 50 年近い 間, 選挙予測に関わって来られた。瀕死の状態になら れてからも, 夏を休んで, 秋に行われるであろう選挙 に備えようと言っておられたと伺った。選挙予測は, 特 に, 結果が直ぐに解り, 予測の成功, 失敗がはっきり と見られると言うことで, 興味深いものがあり,「予測」 の方法に磨きをかけられたということもあるが，それ
以上に選挙行動とその結果, 特に, 国会議員の選挙情 況に特別な関心をもっておられたように見受けられ， それは先生の政治への関心の現れであったかとも推察 できるのである.

彙報 Vol. 12-1 には，予測に関する実証的研究—— 選挙予測の方法論—の長い論文が載つている ${ }^{14)}$.こ こには, 衆議院議員, 参議院議員, についての 1955 年 から'63 年まで, 4 回の選挙のデー夕を用いて行った予 測の方法が詳細に記されている.デー夕は, すべて, 朝 日新聞社世論調查室で集められたものであり，林先生 始め, 統計数理研究所のスタッフはそのデータを扱っ て統計的に予測の方法を探求していった。 世論調查の 結果の比率を 3 次曲線に乗せて, 第 1 次近似值を作り, その值と実際の結果で見られた值との差を, 他の要因 に数量化 1 類の方法を適用した予測值で推定し, 実際 の值に近づけてゆく方法は, 理に適った予測の方法で あったと考えられる。

\section{ここで，一言「統計数理」ということに触れておき} たい。

林先生は「統計数理」という言葉に非常にこだわっ ていらした. 研究所の発足以来, この言葉はその名前 にかぶっているが, 設立当初は, それ程に深い意味合 いはなかったのではないかと想像する. 1940 年代に は, 数理統計という呼び名がよく使われていた。それ は, 統計学の本籍(講座が開かれているところ) は, 理 学部ではなく, 経済学部であったと聞いており, その 関係からも，統計の主流は経済統計にあったように聞 いている.それで, 経済統計とは異なり, 数学的に統 計を扱う分野として数理統計という言葉が一般的には 用いられていたと思う。それを, 何故, 統計数理に言 い換えたのか, その事が, 林先生の科学基礎論学会に 寄せられた論文に明らかに記されている. 即ち,「統計 数理の根本の考え方は, 常に現象解析と言うことを第 一義と考元, 根源に遡って本質的に考えを進めること を重視する．さらに理論的であると同時に実証的であ ること, 実証的であると同時に理論的であること*を 志向し, この意味で, 本来の意味での「操作的」な立 場, な扔, 深く我々の行為と云うものを中心に又根本 にして考えを進め理論を凝出せしめる立場をとつてゆ くのである. また現象解析の妥当性 (validity: 我々に とって何が肝要であるかを考光, 我々の目的をまさし く有用性を以て達成せしめることを第一義とする), 有 効性を根本にして考元を進めること, 逐次近似の考元 
でゆくこと,常に問題発見の形で考えを進めること,を 規範として重視するのである．目的を定め，資料を獲 得し，これを表現し分類し推論し解釈する一聯の操作 に一貫した妥当な理論の筋を通してゆこうとするので ある**.（*実際に我々の操作によって得られるものの みを以て理論を構成することになる。我々は単なる説 明概念として理論を考えるのではなく，予測と言うこ とを念頭におき, 我々が実際に把握し得る限りの事象 と事象との関連性を全体的に追求するのである.; **繰返す様ではあるが，理論は理論，応用は応用と別 けて考える立場ではない. 理論と現象処理とが表裏一 体となって進むでゆくのであって, 所謂理論と応用と

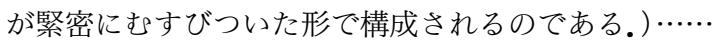
基礎から応用へと一貫した筋のある統計数理こそ我久 の欲するものなのである.」15) と書かれている.そし て, 続いて, 統計の基礎にある確率論としては, 現在 の所, Von Mises の考え方が最も適わしいことが記さ れ, 続いて, 調査対象集団 (universe), 母集団 (population), サンプルが, 説明されており, 予測, 問題の formulation, 推定論, 検定論, ベイズ的な推論の方法, さらに statistical decision functionの考光等があげ られている。

現在, 統計数理という言葉を, この原点に立ち返っ て用いられているか否かは疑わしい所である.

以上, 主として, 1950 年代前後の林先生の考え方, 業 績のほんの一部を辿ってみた。

林先生の理論は, その後もますます研ぎ澄まされ, 洗 練され, 時代の流れに流されることなく, 始めからの, 行為的操作的立場に立ち, データの収集から, 緻密な 分析, 分析を通しての理論の構築をされ, サンプリン
グを基盤とした正統的な社会調査を進め，デー夕解析 の中での新しい方法の開拓を踏まえ, 社会現象, 自然 現象の解析に新しい風を導入すると共に, 広く深い知 見を探索し, 科学の世界に大きな貢献をされてゆかれ た。

先生の死は惜しんでも惜しみ足りないものである.

\section{参 考 文 献}

（以下の文献は著者名のないものはすべて林知已夫先 生の著作であるので，著者名は省略した.）

1）これくていふ序説 1947 ; 統計数理研究所講究 録 第 3 巻第 5 号 $\quad$ p. 62

2) 同上 p. 70

3）同上 p. 70

4）数量化と予測に関する根本概念 1959 ; 統計数 理研究所彙報 第 7 巻第 1 号 p. 55

5）読み書き調査に於ける標本調査計画の概要 1950 ; 統計数理研究所輯報 2 号 p. 67

6) 同上 p. 67

7) 同上 p. 77

8）同上 p. 83

9）林知已夫他 日本人の読み書き能力 1951 ; 東 京大学出版部 $\quad$ p. 228

10）森本栄一: 数量化理論の形成 1997 ; 科学史研 究 No. 202 p. 91

11） 数量化と予測に関する根本概念 1959 ; 統計数 理研究所彙報 第 7 巻第 1 号 $\quad$ p. 55

12）予測の的中について 1951; 統計数理研究所講 究録 第 7 巻第 3,4 号 p. 100

13） 数量化と予測记関する根本概念 1959 ; 統計数 理研究所彙報 第 7 巻第 1 号 p. 55

14）予測に関する実証的研究一選挙予測の方法論— 1964 ; 統計数理研究所彙報 第 12 巻第 1 号

15）現象解析に於ける統計的方法一統計数理の基礎 と展開 - 1955 ; 科学基礎論研究 Vol. 1 No. 2 p. 67 科学基礎論学会 